\title{
Self-assembling peptide-based hydrogel: regulation of mechanical stiffness and thermal stability and 3D cell culture of fibroblasts
}

Article

Accepted Version

Bairagi, D., Biswas, P., Basu, K., Hazra, S., Hermida-Merino, D., Sinha, D. K., Hamley, I. W. and Banerjee, A. (2019) Selfassembling peptide-based hydrogel: regulation of mechanical stiffness and thermal stability and 3D cell culture of fibroblasts. ACS Applied Bio Materials, 2 (12). pp. 5235-5244. ISSN 25766422 doi: https://doi.org/10.1021/acsabm.9b00424 Available at https://centaur.reading.ac.uk/86244/

It is advisable to refer to the publisher's version if you intend to cite from the work. See Guidance on citing.

To link to this article DOI: http://dx.doi.org/10.1021/acsabm.9b00424

Publisher: American Chemical Society (ACS)

All outputs in CentAUR are protected by Intellectual Property Rights law, including copyright law. Copyright and IPR is retained by the creators or other copyright holders. Terms and conditions for use of this material are defined in the End User Agreement. 


\section{www.reading.ac.uk/centaur}

\section{CentAUR}

Central Archive at the University of Reading

Reading's research outputs online 


\title{
Self-assembling Peptide Based Hydrogel: Regulation of Mechanical Stiffness and Thermal Stability and 3D
}

\section{Cell Culture of Fibroblasts}

Dipayan Bairagi ${ }^{\dagger}$, Parijat Biswas ${ }^{\dagger}$,Kingshuk Basu', Soumyajit Hazra ${ }^{\dagger}$, Daniel Hermida-

Merino", Deepak Kumar Sinha , Ian W. Hamley+, Arindam Banerjee ${ }^{\dagger *}$

$\dagger$ School of Biological Sciences, Indian Association for the Cultivation of Science, 2A \& 2B Raja

S. C. Mullick Road, Jadavpur, Kolkata-700032. E-mail: bcab@iacs.res.in

"ESRF - The European Synchrotron, 38043 Grenoble Cedex, France

\#Department of Chemistry, University of Reading, Whiteknights, Reading RG6, 6AD, United Kingdom

KEYWORDS: Peptide gels, Self-assembly, Morphological transformation, Cell culture

\begin{abstract}
A histidine-containing peptide-based amphiphile (P1) forms a transparent hydrogel within a $\mathrm{pH}$ range of 5.5 to 8.5 in phosphate buffer solution. Interestingly, thermal stability and mechanical stiffness are modulated by incorporating different types of dicarboxylic acids into the hydrogels. Inclusion of succinic acid with the molar ratio 2:1 (peptide: dicarboxylic acid) yields improved properties compared to the other tested dicarboxylic acids like oxalic, malonic, glutaric
\end{abstract}


and octanedioic acids. Transmission electron microscopic (TEM) images show the assembly of nanospheres is responsible for the hydrogel obtained from the assembly of native peptide. However, a morphological transformation takes place nanosphere to nanofibers, when the peptide gels with succinic acid. XRD and FT-IR studies reveal interactions between peptide amphiphiles and the acids are responsible for the formation of a two-component hydrogel. Gel stiffness is enhanced considerably upon the addition of succinic acid to P1 with 2:1 molar ratio. The two component gel consisting of peptide and succinic acid has been successfully used for threedimensional cell culture using mouse fibroblast cell line (NIH-3T3). This indicates future promise for the application of such peptide-based gels as tunable biomaterials in cell culture and regenerative medicine.

\section{Introduction}

Self-assembling small molecule soft materials have continued to create interest over the years, due to their diverse applications ${ }^{1-5}$ and easy tunability. ${ }^{6,7}$ Usage of self-assembling peptides as functional materials has numerous advantages, namely, low fabrication cost, good biocompatibility and control over functionality. Amphiphilic peptides are good candidates for selfassociation to form gels under suitable conditions. Peptide hydrogels have been successfully used in optoelectronic devices, ${ }^{8}$ artificial catalysts, ${ }^{9-11}$ templated synthesis of nanoparticles,,${ }^{12,13}$ synthesis of nanohybrids, ${ }^{14-16}$ waste water management ${ }^{17-19}$ and oil spill recovery. ${ }^{20,21}$ Current improvement of bio-medical technology demands gel-like soft materials for efficient culture of stem cells, ${ }^{22}$ therapeutics, ${ }^{23,24}$ immune modulation, ${ }^{25}$ in vitro diagnostics, ${ }^{26}$ wound healing, ${ }^{27-29}$ creation of synthetic extracellular matrix, ${ }^{30-33}$ anti-bacterial agents, ${ }^{34-38}$ drug delivery ${ }^{39-41}$ and many others. ${ }^{42}$ For such applications, gel-forming peptides have great potential, due to their inherently biocompatible nature and low toxicity compared to conventional polymer-based materials. ${ }^{43}$ 
Moreover, it is really challenging to tune the physical properties of covalent polymers, whereas supramolecular assemblies are more flexible, and they are easily stabilized by various noncovalent interactions including H-bonding, van der Waals interactions and $\pi$ - $\pi$ stacking. Design of nanofibrous gel scaffolds is one of the key components in the field of regenerative medicine. ${ }^{44-47}$ In a tissue system, the relation between the cells and the surrounding matrix plays a crucial role in proliferation, differentiation and migration of the cells for tissue repair. Hydrogels are very attractive biomaterials because they provide an excellent environment for cell growth and tissue regeneration. This is due to their high oxygen and nutrient content and metabolite permeability that is required for cell growth. Various research groups over the globe have designed and utilized peptide-based hydrogels as cell culture scaffolds. Ulijn and co-workers have reported fluorenylmethoxycarbony-protected peptide-based hydrogels for 3D culture of bovine chondrocytes. ${ }^{48}$ Recently Tomasini and co-workers have developed a non-cytotoxic pseudopeptide based hydrogel that can be used for re-generative medicine. ${ }^{49}$ These peptides produce a perfect environment upon assembly which mimics the extracellular matrix as a perfect platform for the cell growth. Recently Langhans and co-workers have reported a series of $\beta$-hairpin gelator peptides for 3D cell culture. ${ }^{50}$ another important aspect of these hydrogels is that they are formed by physical crosslinks rather than chemical ones, which make them responsive towards external stimuli, for example, heat, light, $\mathrm{pH}$, salt concentration and mechanical stress and strain. ${ }^{51-53}$ Recently, Gazit and co-workers have reported a peptide based self-healing and conductive hydrogel which supported the growth of electrogenic cells, cardiomyocytes. ${ }^{54}$

In the context of cell culture, the mechanical properties of the matrix are important to realize cell adhesion and proliferation. The extra cellular matrix is a dynamic system with specific mechanical properties and a rationally designed synthetic scaffold must successfully mimic the in vivo 
situation. Different types of cells demand matrices of different stiffness to grow. ${ }^{55}$ Discher and coworkers have shown that it is possible to grow neuronal, muscle, and bone cells from human mesenchymal stem cells by culturing them in gels of varying elastic modulus ${ }^{56}$ Variation of gel stiffness is generally done by varying the concentration of gelator. ${ }^{57}$ However it has been reported that mechanical rigidity can be increased by adding hydrophobic amino acids in the peptide sequence, or by creating chemical crosslinking through oxidation of cysteine side chains or by using multicomponent systems. ${ }^{58}$

The comprehensive goal of this work was to develop a cheap, non-cytotoxic, nanofibrous hydrogel, which can act as a scaffold for adherence and proliferation of cells. We demonstrate that it is possible to regulate gel stiffness (mechanical strength) and thermal stability by incorporating different dicarboxylic acids (oxalic acid, succinic acid, glutaric acid and octanedioic acid) as they promote extended non-covalent interaction between the histidine containing, $\mathrm{N}$-termini free peptide molecules. By tuning the elasticity of dicarboxylic acid incorporated peptide hydrogel through the variation of gelator concentration and chain length of dicarboxylic acids, a successful scaffold for mammalian fibroblast cell culture has been achieved. Among all the acids tested, succinic acid leads to the highest gel thermal stability and mechanical stiffness at a given concentration, thus peptide-succinic acid hydrogels at physiological $\mathrm{pH}(7.5)$ have been selected as our material of choice. Interestingly, it has been observed that the extended interaction through succinic acid spacer changes the morphology of the hydrogel to a nanofibrous one, which mimics the extracellular matrix protein more than the native peptide gel with a beads-in-a-garland type morphology. Interestingly, 3D cell culture ise possible in hydrogel with a storage modulus of 4 $\mathrm{kPa}$, whereas for a stiffer gel with storage modulus of $9.7 \mathrm{kPa}$, only $2 \mathrm{D}$ culture was possible on the surface of the hydrogel. Thus, a two-component hydrogel with a suitable gel stiffness can serve 
as a successful cell culture scaffold for NIH-3T3 mouse fibroblast cells and this holds future promise in the field of short peptide based regenerative medicine and tissue engineering.

\section{MATERIALS AND METHODS}

Chemicals and Cell line: 11-Aminoundecanoic acid was purchased from Sigma-Aldrich. Lhistidine, L-isoleucine, DCC, hydroxybenzotriazole (HOBt), $\mathrm{NaOH}$, chloroform, methanol, silica gel (100-200 mesh), Et ${ }_{2} \mathrm{O}$, petroleum ether, EtOAc, and DMF were purchased from SRL (India). Formic acid, succinic acid, oxalic acid dehydrate, sodium dihydrogen phosphate, and disodium hydrogen phosphate were purchased from Merck. Glutaric acid and octanedioic acid were obtained from SpectrochemPvt. Ltd. The water used in all experiments was Millipore Milli-Q grade. Dulbecco's modified Eagle medium (DMEM) supplemented with 10\% fetal bovine serum (FBS), penicillin, streptomycin were procured from Himedia, NIH-3T3 cells were from ATCC.

Synthesis and Characterization of Peptide: The tripeptide was synthesized by conventional solution phase methods by using a racemization-free fragment condensation strategy. All steps of the synthetic details are provided in the supporting information. The final compound was fully characterized by mass spectrometry, ${ }^{1} \mathrm{H}$ NMR spectroscopy and ${ }^{13} \mathrm{C}$ NMR spectroscopy. All NMR studies were carried out on a Bruker DPX400 MHz or Bruker DPX500 MHz spectrometer at 300 K. Concentrations were in the range 5-10 $\mathrm{mmol}$ in $\mathrm{CDCl}_{3}$ or DMSO- $\mathrm{d}_{6}$. Mass spectra were recorded on a Q-Tofmicro ${ }^{\mathrm{TM}}$ (Waters Corporation) mass spectrometer by positive mode electrospray ionization process.

\section{Transmission electron microscopy (TEM) study:}

The morphology of the hydrogel was investigated by using a transmission electron microscope. The samples were prepared by depositing $10 \mu \mathrm{L}$ of gel sample $(0.002 \% \mathrm{w} / \mathrm{v}$ in the case of dilute 
sample and $0.01 \% \mathrm{w} / \mathrm{v}$ for concentrated ones) onto a TEM grid (300 mesh $\mathrm{Cu}$ grid). After 2 min excess fluid was soaked. Then, the grid was dried under vacuum at $27^{\circ} \mathrm{C}$ for twelve hours. Images were recorded on a JEOL electron microscope at an accelerating voltage of $200 \mathrm{kV}$.

\section{Fourier Transform Infrared (FTIR) study:}

Fourier transformed Infrared spectroscopy study of the xerogels were done in the solid state $(\mathrm{KBr}$ matrix) using a Nicolet 380 FT-IR spectrophotometer (Thermo Scientific).

\section{Powder X-ray diffraction study (XRD) study:}

The low angle $\mathrm{X}$-ray ( scans over $2 \theta=0.6^{\circ}-5^{\circ}$ ) diffraction studies of xerogels were carried out using an X-ray diffractometer (Bruker AXS, Model D8 Advance). The instrument was operated at a 40 $\mathrm{kV}$ voltage and $40 \mathrm{~mA}$ current using Ni-filtered $\mathrm{CuK} \alpha$ radiation and the instrument was calibrated with a standard $\mathrm{Al}_{2} \mathrm{O}_{3}$ (corundum) sample before use. The scintillation counts detector was used with scan speed $2 \mathrm{~s}$ and step size $0.02^{\circ}$. For wide angle X-ray (For scans over $2 \theta=10^{\circ}-50^{\circ}$ ) diffraction studies, the same samples were studied under Rigaku, SmartLab X-Ray Diffractometer, operated at $9 \mathrm{~kW}(45 \mathrm{kV}, 200 \mathrm{~mA})$ using Ni filtered CuKaradiation and 1D detector with scan speed $0.3 \mathrm{~s}$ and step size $0.02^{\circ}$. Samples were prepared by freeze drying the hydrogels

Small-Angle X-ray Scattering (SAXS): Simultaneous SAXS/WAXS experiments were performed at the NCD station of the ALBA syncrotron (Cerdanyola del Vallès, Spain). The sample-to-SAXS detector distance was ca. $2592 \mathrm{~mm}$ using a wavelength of $0.998 \AA$. A DectrisPilatus 1M detector was used to record the 2D SAXS patterns. Standard corrections for sample absorption and background subtraction were performed. The data were normalized to the intensity of the incident beam (in order to correct for primary beam intensity fluctuations) and were 
corrected for absorption and background scattering The scattering patterns from AgBe were used to calibrate the wavevector scale of the scattering curve. WAXS patterns were collected using a Rayonix Lx 255-HS detector at a distance of $135 \mathrm{~mm}$ from the sample. The wavenumber $\mathrm{q}=4 \pi / \lambda$ $\sin \theta$ scale for WAXS experiments was calibrated using corundum. .

Cell culture and Microscopy: Custom made $35 \mathrm{~mm}$ plastic petri dishes, with a concentric hole of diameter $10 \mathrm{~mm}$, were fitted with 22x22 $\mathrm{mm}$ glass coverslips on the bottom using biocompatible silicone grease. A sterile rubber O-ring of diameter $12 \mathrm{~mm}$ was attached on top of the hole, also using silicone grease, creating a cylindrical enclosure of height $\sim 3 \mathrm{~mm}$. Then $100 \mu \mathrm{L}$ of the gel, pre-heated to the sol state, was poured onto the glass inside the hole and allowed to cool down and solidify. NIH $3 \mathrm{~T} 3$ cells, cultured at $37^{\circ} \mathrm{C} / 5 \% \mathrm{CO}_{2}$, in Dulbecco's modified Eagle medium (DMEM), supplemented with 10\% fetal bovine serum (FBS), 100 units/ml of penicillin, and 100 $\mu \mathrm{g} / \mathrm{ml}$ of streptomycin were grown up to $85-90 \%$ confluence, and then harvested using $0.5 \mathrm{mM}$ EDTA. $10^{4}$ cells suspended in $100 \mu \mathrm{L}$ culture media were seeded on the gel only inside the space enclosed by the O-ring, and the dish was kept undisturbed for at least 10 minutes to allow the cells to settle. The dish was then filled with $3 \mathrm{~mL}$ of culture medium and stored in the cell culture incubator. Cells were then observed every 6 hours using an inverted microscope (Zeiss AxioObserver $\mathrm{Z1}$ ). Images were taken at 10x and 20x magnification using a CMOS camera (Hamamatsu Orca Flash 4.0 V2). Cells were stained with Hoechst 3342 to visualize the nucleus.

MTT Assay: An MTT assay ${ }^{59}$ was performed to assess the viability of cells in hydrogel environment. Mitochondrial active succinate dehydrogenase converts MTT (3-[4,5-dimethylthiazol-2-yl]-2,5diphenyl tetrazolium bromide into purple colored formazan crystals, and its absorbance at $570 \mathrm{~nm}$ is 
proportional to the number of live cells. $10^{4}$ cells were seeded for $48 \mathrm{~h}, 36 \mathrm{~h}, 24 \mathrm{~h}$ and $12 \mathrm{~h}$ from the time of addition of the MTT in a 48 well plate, with or without hydrogel. Gels of two different concentrations $(1 \%$ and $1.5 \% \mathrm{w} / \mathrm{v})$ were used to assess the effect of $2 \mathrm{D}$ and $3 \mathrm{D}$ environment on cell proliferation. Cells in each well were simultaneously treated with MTT $(0.5 \mathrm{mg} / \mathrm{mL})$ for 3 hours at 37 ${ }^{\circ} \mathrm{C} / 5 \% \mathrm{CO}_{2}$. After incubation, $200 \mu \mathrm{L}$ of DMSO was added to each well and absorbance at 570nm was measured on a SpectraMax M2 spectrometer (Molecular Devices). Each condition was repeated thrice and errors bar representing standard deviation are plotted as part of the assessment of cell viability in the hydrogel environment, with the cells grown in standard poly-L-Lysine coated plastic surface as control.

\section{RESULTS AND DISCUSSION}

The L-histidine containing C-terminal protected tripeptide $\mathrm{NH}_{2}$-His-Ile-AUDA-COOMe (AUDA = 11-aminoundecanoic acid) P1 (Figure 1a) was synthesized in solution phase and subsequently purified and characterized.

Gelation Study: The gelation property of $\mathbf{P 1}$ was tested in the full spectrum of $\mathrm{pH}$ of phosphate buffer solutions (PBS) and it was found that a transparent hydrogel was formed between $\mathrm{pH} 5.5$ to 8.5. For each gelation study, $4 \mathrm{mg}$ of the solid peptide was taken in a glass vial and dissolved in $1 \mathrm{~mL}$ of PBS by heating with a hot-gun until a clear solution was obtained. The solution was allowed to equilibrate at room temperature $\left(27^{\circ} \mathrm{C}\right)$ and it turned translucent as it was cooled down within 60 seconds. Interestingly, it became transparent as hydrogel formation took place. The gel melting temperature of the peptide hydrogel at $\mathrm{pH} 7.46$ was found to be $44{ }^{\circ} \mathrm{C}(0.5 \% \mathrm{w} / \mathrm{v})$. To strengthen the network of the hydrogel, we have incorporated various dicarboxylic acids into the 
peptide gel network. For each gelation experiment $4 \mathrm{mg}\left(8.6 \times 10^{-3} \mathrm{mM}\right)$ of solid peptide was placed in $950 \mu \mathrm{L}$ of PBS (pH 7.46), dissolved by careful heating with a hot-gun and $50 \mu \mathrm{L}$ of $85 \mathrm{mM}(4.3$ $\mu$ moles) dicarboxylic acid solution (oxalic acid, succinic acid, glutaric acid and octanedioic acid) was added to it to obtain the peptide-dicarboxylic acid based two-component hydrogels. It was observed that the gel melting temperature significantly increased upon the addition of dicarboxylic

(a)

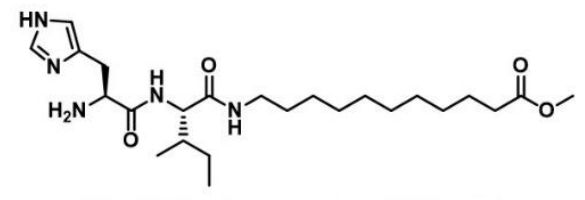

(c)

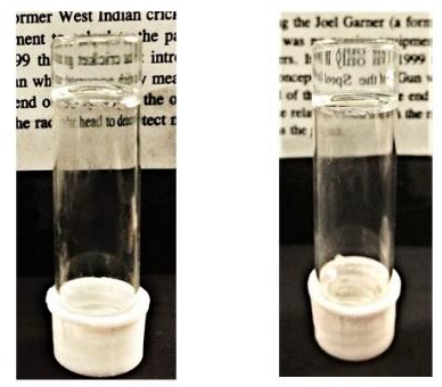

(b)

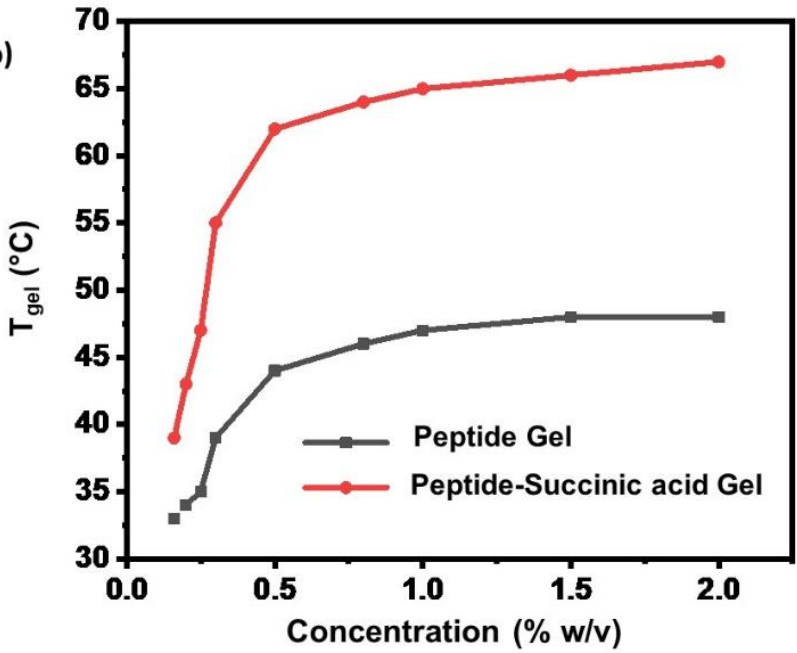

acids (Table 2 in supporting information). The most prominent improvement was shown for peptide-succinic acid gel, which showed a $\mathrm{T}_{\text {gel }}$ of $62{ }^{\circ} \mathrm{C}(0.5 \% \mathrm{w} / \mathrm{v})$. The native hydrogel as well as the gels obtained after the addition of succinic acid were found to be transparent and suitable for microscopic studies (Figure 1c). A comparative study of gel melting temperature versus concentration of gelator, between native peptide gel and the peptide-succinic acid gel shows the improvement of thermal stability over all concentration range. It is noted that $\mathrm{T}_{\text {gel }}$ values become essentially independent of concentration above $1 \% \mathrm{w} / \mathrm{v}$ for both the hydrogels (Figure $1 \mathrm{~b}$ ). 
Figure 1. (a) Chemical structure of peptide P1; (b) Gel melting temperature $\left(\mathrm{T}_{\text {gel }}\right)$ of hydrogel obtained from $\mathbf{P 1}$ and hydrogel obtained from $\mathbf{P 1}$ added with succinic acid, plotted against various concentrations; (c) Inverted vial images of peptide gel (left) and Peptide-succinic acid gel (right).

Morphology: High resolution transmission electron microscopic (HR-TEM) studies were performed to examine the morphologies of the gelators in different assembled states (aggregated non-gel and gel states). Samples of $\mathbf{P 1}$ hydrogels were made at two different concentrations to understand the nature of the aggregation. The HR-TEM images obtained from the dilute solution reveals the formation of nanospheres (Figure 2a). In the non-gel state the nanospheres are obtained from the aggregation of gelator molecules and these nanospheres are aligned in a regular fashion forming a bead-on-a-garland like structure (Figure 2b). Although this is a rare phenomenon, a few examples have been observed for the spherical morphology in gels formed by assembly of small molecules. ${ }^{60-61}$ Thethree-dimensional porous network structure formed by adhered interconnecting nanospheres shows a beads-on-a-string-like morphology in the concentrated gel phase. This cagelike porous structure is able to entrap a lot of water molecules into it to form a self-supporting hydrogel. Interestingly, a change in the morphology is observed in the two-component gel consisting of the peptide gelator and succinic acid. In presence of the acid, a well-resolved interconnected helical nanofibrous network structure is obtained (Figure 2d). The network shows the presence of both right- and left-handed helicity (Figure 2e). The nanofibrous network is well adapted to support the proliferation of mammalian cells. The images reveal a remarkable transition from a nanosphere (soluble aggregated non-gel state) to a beads-on-a-string morphology in the gel state. A few previous reports describe morphological transformations within hydrogel systems. ${ }^{62-}$ ${ }^{64}$ However, it is rare to observe a drastic change in morphology (interconnected nanospheres to 
helical nanofibres) from one gel phase (only peptide) to another gel phase (peptide + succinic acid).

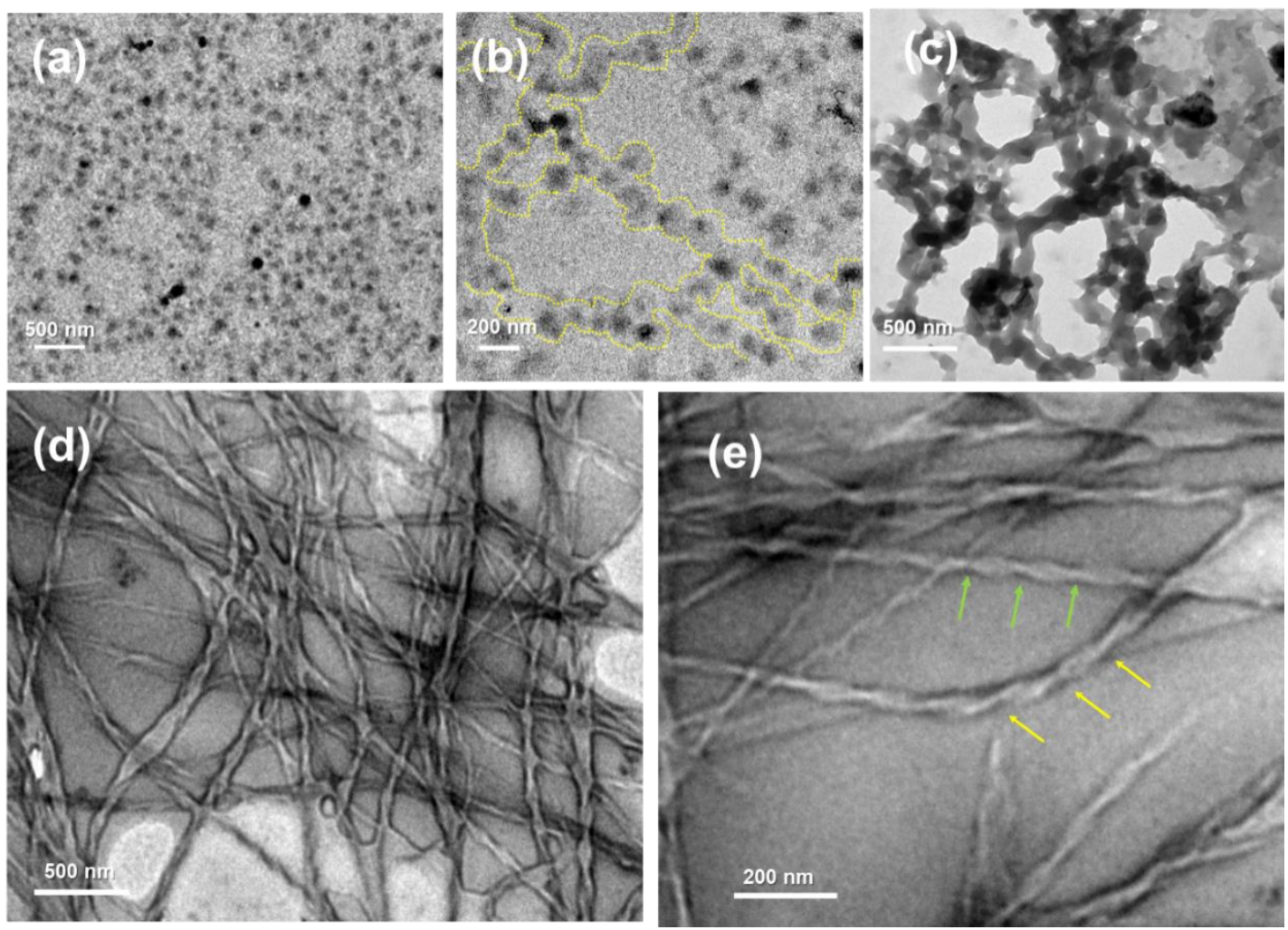

Figure 2. High Resolution Transmission Electron Microscopic images showing(a) nanospheres composing the peptide hydrogel; (b) magnified image of the nanospheres arranged in a networklike arrangement (yellow dotted line highlights the pattern); (c) 3D network assembly of the nanospheres; (d) Helical fibrous morphology of peptide-succinic acid hydrogel, (e) Individual fibers of peptide-succinic acid gel. (green arrows and yellow arrows show two different kinds of handedness in the helices.)

Fourier Transformed-Infrared (FT-IR) Spectroscopic Study: Intense peaks at $3291 \mathrm{~cm}^{-1}$ corresponding to $\mathrm{N}-\mathrm{H}$ stretching vibration, $1637 \mathrm{~cm}^{-1}$ corresponding to amide $\mathrm{C}=\mathrm{O}$ stretching (amide I) and $1555 \mathrm{~cm}^{-1}$ (N-H bending), suggest a strongly hydrogen bonded network in the P1 
hydrogel at physiological $\mathrm{pH}$ (Figure S4). ${ }^{65}$ Similar kind of IR signatures were found in two component gels with various dicarboxylic acids. Moreover, the decrease in the stretching frequency of ester $\mathrm{C}=\mathrm{O}$ to $1730 \mathrm{~cm}^{-1}$ suggests bond elongation, which indicates its participation in hydrogen bonding (the ester $\mathrm{C}=\mathrm{O}$ stretching generally appears within the $1735-50 \mathrm{~cm}^{-1}$ range). ${ }^{66}$ A xerogel obtained from the two-component gel containing peptide and succinic acid shows symmetric and antisymmetric stretching of carboxylate anion of succinic acid at $1420 \mathrm{~cm}^{-1}$ and $1570 \mathrm{~cm}^{-1}$ respectively along with the other peaks observed for the peptide-only gel (Figure S4).

Powder X-Ray Diffraction Studies: To probe the molecular packing within the gels, X-ray diffraction studies of powdered freeze-dried gels were performed. In the low angle diffraction pattern, for the peptide only gel, we observed a peak at $\mathrm{D}=30.26 \AA\left(2 \theta=2.84^{\circ}\right)$, which can be attributed to the length of two peptide molecules interdigitated along the hydrocarbon chain (Figure 3a) (Estimated molecular length of $\mathbf{P 1}$ is $24.62 \AA$ ). A similar packing was reported previously for a lipidated histidine dipeptide gelator. In the wide-angle powder x-ray diffraction patterns, peaks at $4.78 \AA\left(2 \theta=18.05^{\circ}\right)$ are ascribed to the distance between $\beta$-strands and the peak at $9.87 \AA\left(2 \theta=8.71^{\circ}\right)$ corresponds to the distance between two stacked $\beta$ sheets (Figure $3 \mathrm{~b}$ ). ${ }^{67}$ Interestingly four peaks at $5.48 \AA\left(2 \theta=15.72^{\circ}\right), 4.39 \AA\left(2 \theta=19.66^{\circ}\right), 3.74 \AA\left(2 \theta=23.13^{\circ}\right), 3.33$ $\AA\left(2 \theta=26.00^{\circ}\right)$ correspond to $\mathrm{D} / 6, \mathrm{D} / 7, \mathrm{D} / 8$ and $\mathrm{D} / 9$ respectively. This indicates a lamellar type of packing arrangement. ${ }^{68}$ Investigation of small angle diffraction pattern from a succinic acidpeptide xerogel showed a peak at $\mathrm{D}^{\prime}=59.27 \AA\left(2 \theta=1.45^{\circ}\right)$. The total molecular length of two peptide molecules and a succinic acid (5.05 $\AA$ ) (estimated in Chem3D Pro 12.0 software) is 54.3 $\AA$ A. However, if the succinate anion and the peptide molecules are connected through hydrogen bonding between imidazole $\mathrm{N}-\mathrm{H}$ and carboxylate $\mathrm{O}$, the overall supramolecular unit length increases by twice thef $\mathrm{N}-\mathrm{H} \cdots \mathrm{O}$ hydrogen-bond length ${ }^{69,70}(2.7 \AA \times 2=5.4 \AA)$ and it becomes 59.69 
$\AA$, which is in accordance with the d-spacing found by XRD (Figure 3c). So, we can conclude that the two peptide molecules are interconnected by a centrally located succinic acid moiety through hydrogen bonding. Furthermore, three peaks at $6.13 \AA\left(2 \theta=14.05^{\circ}\right), 5.50 \AA\left(2 \theta=15.67^{\circ}\right), 4.85$ $\AA\left(2 \theta=17.81^{\circ}\right)$ can be interpreted as $\mathrm{D}^{\prime} / 10, \mathrm{D}^{\prime} / 11$ and $\mathrm{D}^{\prime} / 12$, and this suggests the length corresponding to two terminally located peptide molecules hydrogen bonded to a centrally positioned succinic acid moiety (Figure $3 \mathrm{~d}$ ). Another set of peaks was found at $3.90 \AA(2 \theta=$ $\left.22.22^{\circ}\right), 3.66 \AA\left(2 \theta=23.62^{\circ}\right), 3.36 \AA\left(2 \theta=25.82^{\circ}\right)$, assigned as $\mathrm{D}^{\prime} / 15, \mathrm{D}^{\prime} / 16$ and $\mathrm{D}^{\prime} / 17$. It shows that the peptide succinic acid gel packs in a lamellar fashion. Again, the d-spacing of $4.78 \AA$ ( $2 \theta=$ $\left.18.05^{\circ}\right)$ is the distance between $\beta$-strands.

(a)

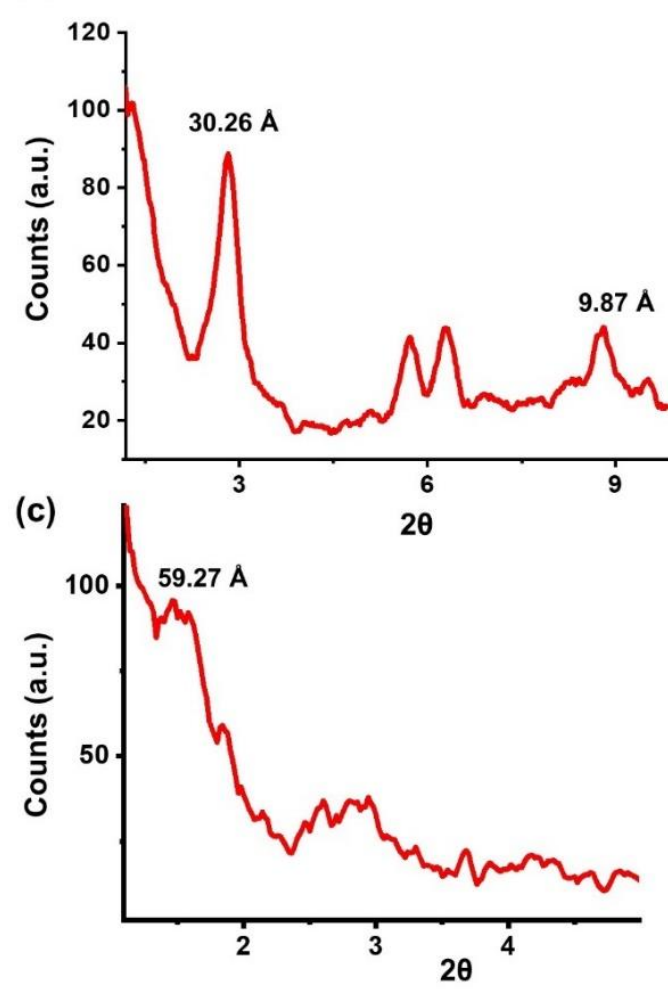

(b)

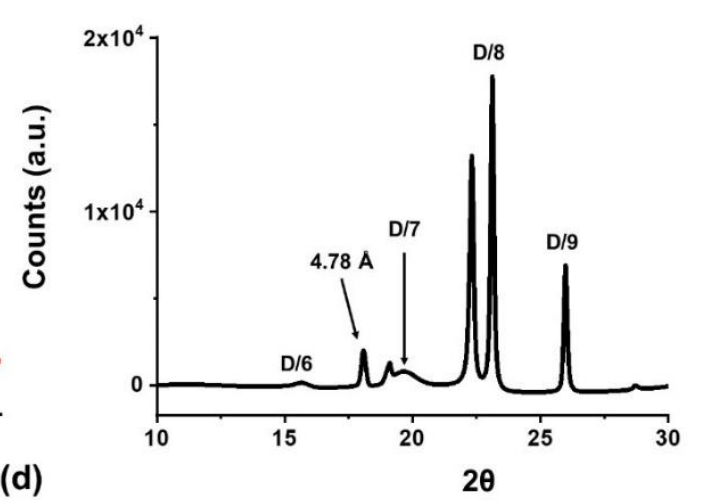

(d)

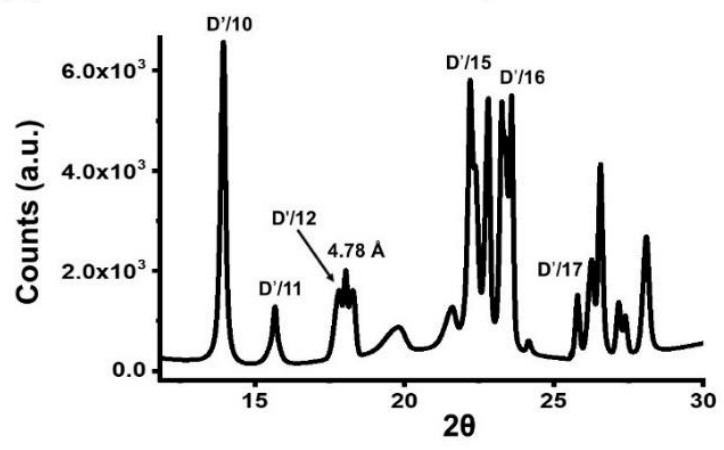


Figure 3.(a) Low (b) Wide-angle X-ray diffraction pattern recorded for xerogel obtained from peptide hydrogel (c) Low-angle (d) Wide-angle X-ray diffraction pattern recorded for xerogel obtained from succinic acid-peptide hydrogel.

Small-Angle X-ray Scattering (SAXS) Study: To visualize single molecular length and mode of packing of the peptide in the (undried) gel state, small angle X-ray scattering (SAXS) was carried out. The d-spacing of $30.2 \AA$ (Figure S5) can be assigned to the length of a layered structure of two interdigitated peptides. This data supports the low angle powder XRD data of the dried peptide gel. On the basis of SAXS and PXRD and FT-IR studies, probable models for the molecular packing pattern of the gel phase has been constructed in Figure S6 and S7 for the native peptide gel and the two-component gel (obtained from peptide and succinic acid) respectively.

Rheological Study: The stiffness of the extracellular matrix is known to influence cell physiology, and thus is a crucial parameter to address when developing hydrogels as models for tissue systems. The degree of stiffness of the peptide hydrogels and peptide-dicarboxylic acid gels were systematically measured and compared to get an insight into how incorporation of these acids affects the mechanical strength of the native gel. Time sweep rheology data of the peptide gel was also recorded to quantify the visible thixotropic property of the hydrogel. Firstly, the frequency sweep experiment was done for peptide hydrogel with gelator concentration $0.5 \%(\mathrm{w} / \mathrm{v})$ where the two moduli, i.e. storage modulus $\left(G^{\prime}\right)$ and loss modulus $\left(G^{\prime \prime}\right)$ were plotted against angular frequency $(\omega)$ ranging from $8-100 \mathrm{rad} / \mathrm{s}$, at a constant strain of $0.1 \%$. The moduli show an insignificant dependence on angular frequency (Figure 4A). This indicates the formation of a stable gel. To attain higher stiffness, we increased the concentration of the gelator to $1.0 \% \mathrm{w} / \mathrm{v}$ and $1.5 \% \mathrm{w} / \mathrm{v}$. While doubling the concentration of the peptide increased the elastic modulus by a factor of two, tripling the concentration increased the elastic modulus ten fold. At $\omega=50 \mathrm{rad} / \mathrm{s}, G^{\prime}$ 
is $690 \mathrm{~Pa}, 1402 \mathrm{~Pa}$ and $7006 \mathrm{~Pa}$ for $0.5 \%, 1 \%, 1.5 \% \mathrm{w} / \mathrm{v}$ hydrogel respectively (Figure 4a). The time-dependent step-strain experiment was performed with a time step of $125 \mathrm{~s}$. Initially the strain was kept constant at $0.1 \%$ then the strain was increased to $30 \%$ at which point the gel ruptured. The reformation of the gel takes place as the strain is reduced to $0.1 \%$ at the next cycle. The process was continued to 3 cycles to show reproducibility (Figure 4b).
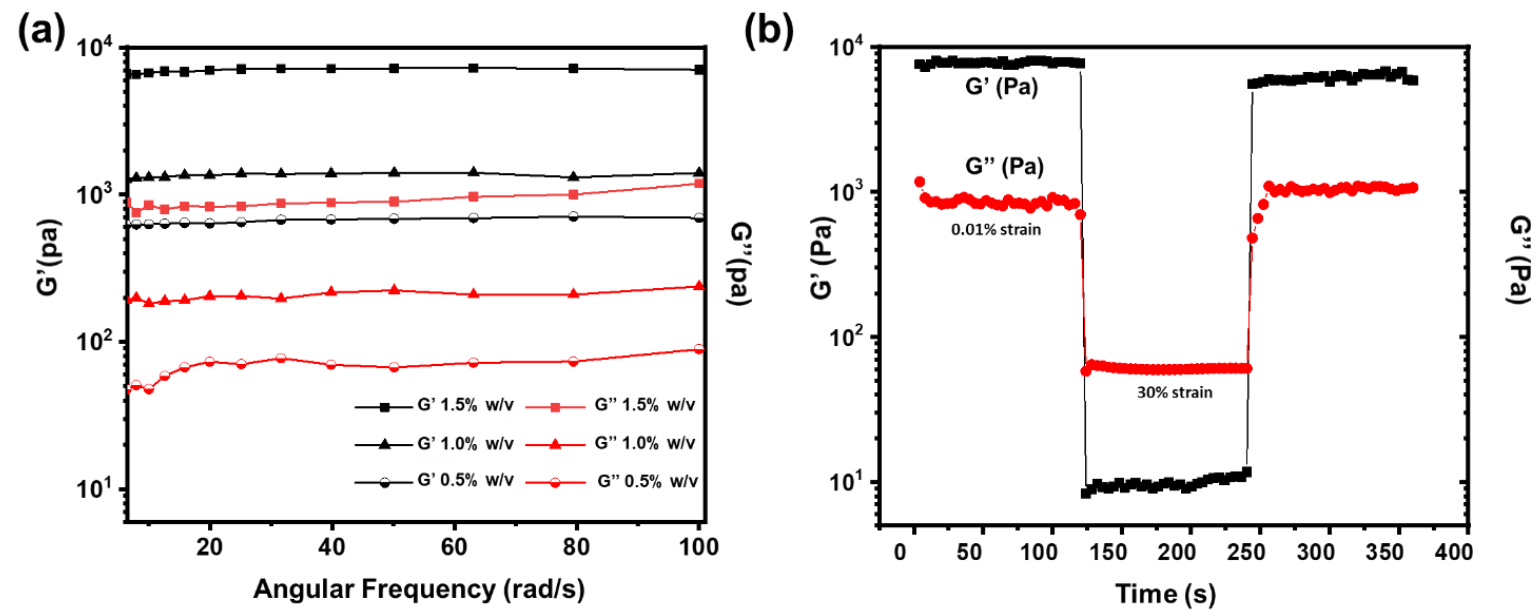

Figure 4. (a) Elastic modulus $G^{\prime}$ and Loss modulus $G^{\prime \prime}$ of hydrogels of peptide $\mathbf{P 1}$ in three different concentrations, (i) $1.5 \% \mathrm{w} / \mathrm{v}$, (ii) $1 \% \mathrm{w} / \mathrm{v}$, (iii) $0.5 \% \mathrm{w} / \mathrm{v}$ and (b) Step strain experiment for $1.5 \%$ w/v of peptide $\mathbf{P 1}$ hydrogel with 125 s step length, confirming thixotropic behavior of the hydrogel. 
Dicarboxylic acids with varying chain lengths were incorporated with an expectation of extended supramolecular interactions between free carboxylic acid groups and peptide molecules with free $\mathrm{N}$ terminus, as well as the imidazole side chain of the histidine residue. Peptide-dicarboxylic acids at $1 \% \mathrm{w} / \mathrm{v}$ concentration of peptide and acids taken in 1:2 molar ratios indeed showed increased storage modulus, to different degrees, for different acids (Figure 5).

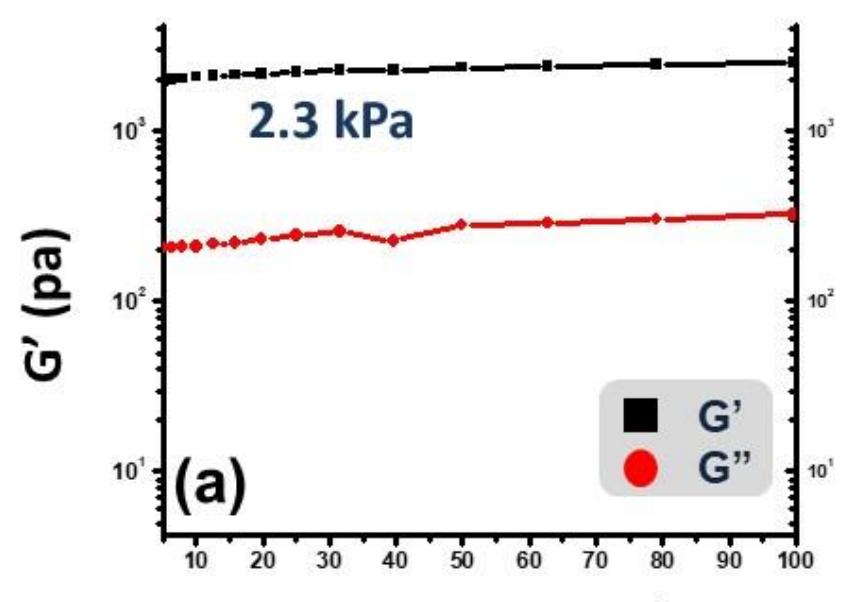

Angular Frequency (rad/s)

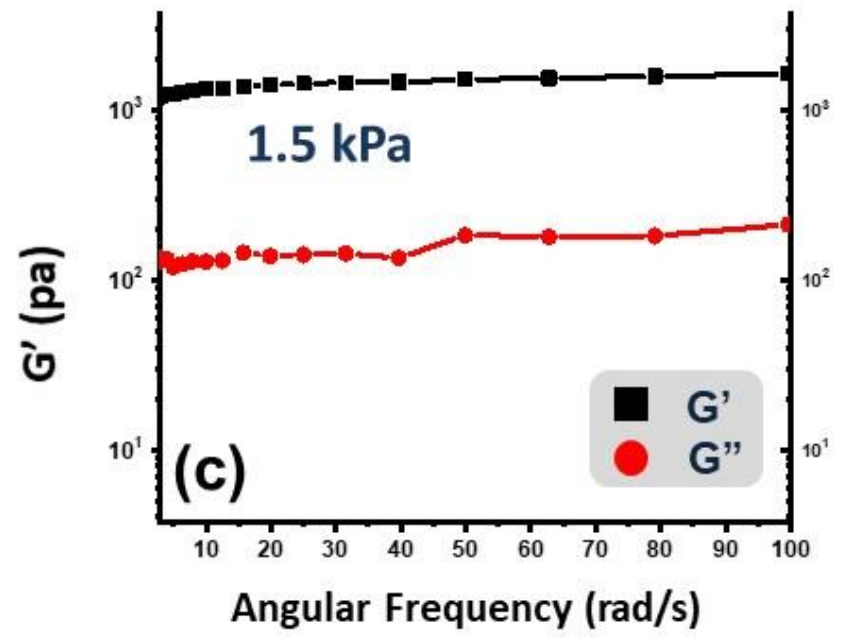

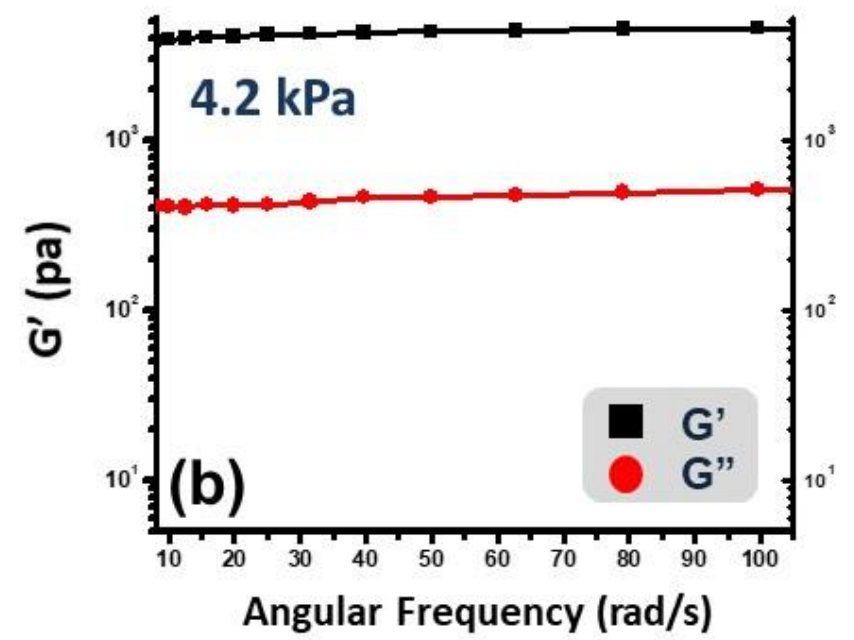

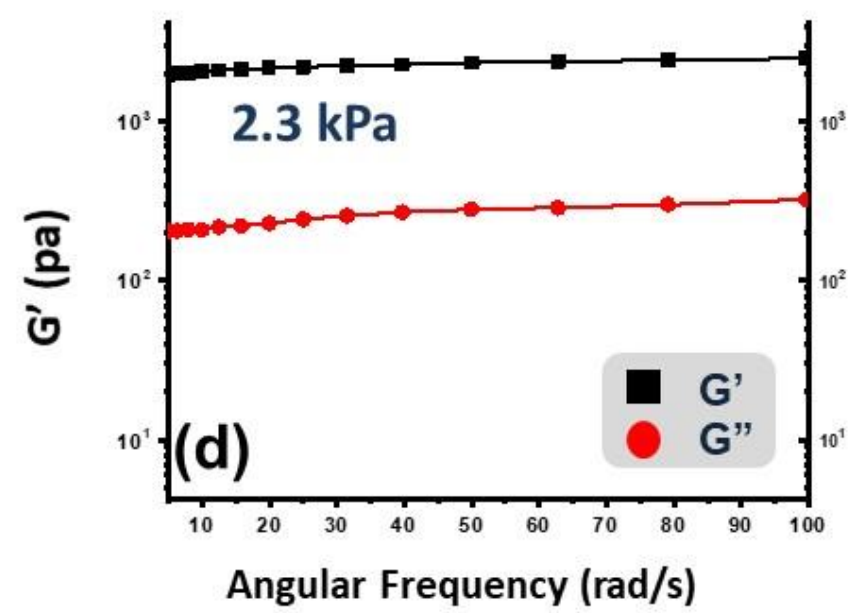

Figure 5. Elastic modulus $G^{\prime}$ and Loss modulus $G^{\prime \prime}$ of hydrogels of peptide P1 with different additives, (a) oxalic acid, (b) succinic acid, (c) glutamic acid, (d) octanedioic acid, with value of 
$G^{\prime}$ at $50 \mathrm{rad} / \mathrm{s}$ indicated for each case. Peptide and dicarboxylic acid were tin a 2:1 molar ratio with $1 \%(\mathrm{w} / \mathrm{v})$ peptide.

The most significant enhancement of mechanical strength was shown by the addition of succinic acid (Figure 5). Due to its optimal mechanical and thermal response, the transparent gels of peptide-succinic acid were used in cell culture. Stiffness tuning of the peptide-succinic acid gel could be achieved by varying the concentration from $0.5 \%$ to $2.0 \% \mathrm{w} / \mathrm{v}$ (Figure 6 ). At $\omega=50 \mathrm{rad} / \mathrm{s}$, $G^{\prime}$ is $879 \mathrm{~Pa}, 4340 \mathrm{~Pa}, 8357 \mathrm{~Pa}$ and $9729 \mathrm{~Pa}$ for $0.5 \%, 1 \%, 1.5 \%$ and $2 \% \mathrm{w} / \mathrm{v}$ hydrogel respectively

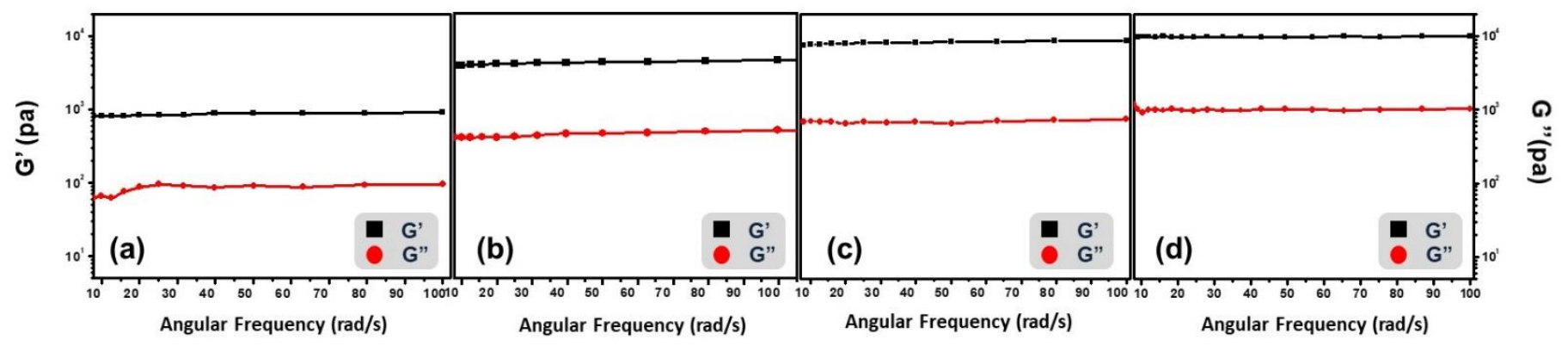

Figure 6. Elastic modulus G' and Loss modulus G' of hydrogels of two component gel of peptide and succinic acid in different concentrations of peptide and succinic acid, (a) $0.5 \% \mathrm{w} / \mathrm{v}$, (b) $1 \%$ $\mathrm{w} / \mathrm{v}$, (c) $1.5 \% \mathrm{w} / \mathrm{v}$, (d) $2 \% \mathrm{w} / \mathrm{v}$.

Cell culture Experiments: The histidine-based hydrogel is optically transparent and it forms gels at a physiological $\mathrm{pH}$ of 7.5. Free $\mathrm{NH}_{2}$ groups give it a net positive charge at $\mathrm{pH} 7.5$, which would facilitate adhesion of negatively charged cell membranesthe substrate. Moreover, the stiffness of the gel can be tuned by varying the gelator concentration. This makes out hydrogel system a good candidate as an extracellular matrix mimic. Due to transparency and good rheological response, the hydrogel of $\mathbf{P 1}$ was initially used to investigate whether cells can grow on them or not. The fibroblast 
cell line NIH 3T3 was employed for cell culture experiments. Cell culture was attempted on the peptide gel $(1.5 \% \mathrm{w} / \mathrm{v})$ with stiffness of $7 \mathrm{kPa}$, but it was found that the gel would disappear readily within 6 hours at the incubator temperature of $37^{\circ} \mathrm{C}$. This is because the gel melting temperature of the pure peptide gel at $1.5 \% \mathrm{w} / \mathrm{v}$ gelator concentration is $48{ }^{\circ} \mathrm{C}$ and this makes it slightly unstable at the physiological temperature of $37^{\circ} \mathrm{C}$. To primarily increase the thermal stability of the hydrogel, we incorporated several dicarboxylic acids along with the peptide gelator. As detailed above, the peptide-succinic acid gel gave the best thermal and mechanical response. The nanofibrous morphology of the peptide-succinic acid gel also encouraged us to investigate its possibility of acting as an extracellular matrix for the cell growth and proliferation. The culture was done on petri dishes using a sterile rubber O-ring of diameter $12 \mathrm{~mm}$ to create a cylindrical enclosure of height $\sim 3 \mathrm{~mm}$. Cell culture was first performed on $2 \% \mathrm{w} / \mathrm{v}$ peptide-succinic acid gel $\left(G^{\prime}=9.7 \mathrm{kPa}\right)$. Cell growth was monitored for 36 hours at 6 hour intervals, after which the gel mass generally was detached from the glass surface, making microscopy difficult. that the images in Figure 7 show that the cells are able to grow on the two-component peptide-based gel surface up to 36 hours without any problem. The cell morphology was generally circular, possibly due to absence of stable focal adhesions. ${ }^{70-72}$ Fibroblasts are also known to tune their internal stiffness to enable survival and spreading on substrates with lower stiffness, which often results in a rounded morphology. ${ }^{73}, 74$ The cells that did have elongated morphology could have secreted ECM proteins (locally) as typical of fibroblasts ${ }^{74}$ (Figure $7 b$ ). When cells were cultured on a lower concentration $1 \% \mathrm{w} / \mathrm{v}$ gel of a lower $\mathrm{G}^{\prime}=4 \mathrm{kPa}$, it was convincingly apparent that they could penetrate deep inside the gel (Figure 7c, 7d, 7e). The cells are alive and healthy as evident from the images inFigure 7d. It is known that contraction forces generated by cells on the culture substrate can influence the mechanical architecture of the substrate. ${ }^{76}$ In the case of the P1succinic acid gel, the cellular traction stress could have broken the gel in a localized manner, thus 
enabling the cells to travel inside by constantly dissolving the gel beneath them. The gel above the cells could then recovers from solution state to reform the gel due to its thixotropic property, after some time. A MTT cell survival assay was performed to examine the influence of peptide-succinic acid hydrogel on cell viability over time. The assay reveals that the $2 \mathrm{D}$ or $3 \mathrm{D}$ environment provided by the peptide gel has no detrimental effect on cell viability (Figure 7f). This indicates that the peptidebased hydrogel obtained from gelator P1 and succinic acid is not cytotoxic, and it can be used to mimic the extracellular matrix to culture fibroblasts in vitro up to two days at least.

The aforementioned study suggests that the tuning of the thermal stability of the hydrogel enhances the gel stability for a sufficiently long time that is needed for the cell culture. Moreover, the mechanical stiffness of the hydrogel can be modulated according to the traction stress generated by the cell type to choose the culture environment as $2 \mathrm{D}$ or $3 \mathrm{D}$. Relatively less stiff gel $\left(G^{\prime}=4 \mathrm{kPa}\right)$ is well suited for 3D culture, as it promotes selective penetration of cells into the gel phase material, while increasing the gel stiffness above the cellular traction stress provides a platform for 2D culture on the hydrogel surface. Here, gel stiffness was optimized for successful culture of NIH$3 \mathrm{~T} 3$ cells in 2D and 3D environments. 

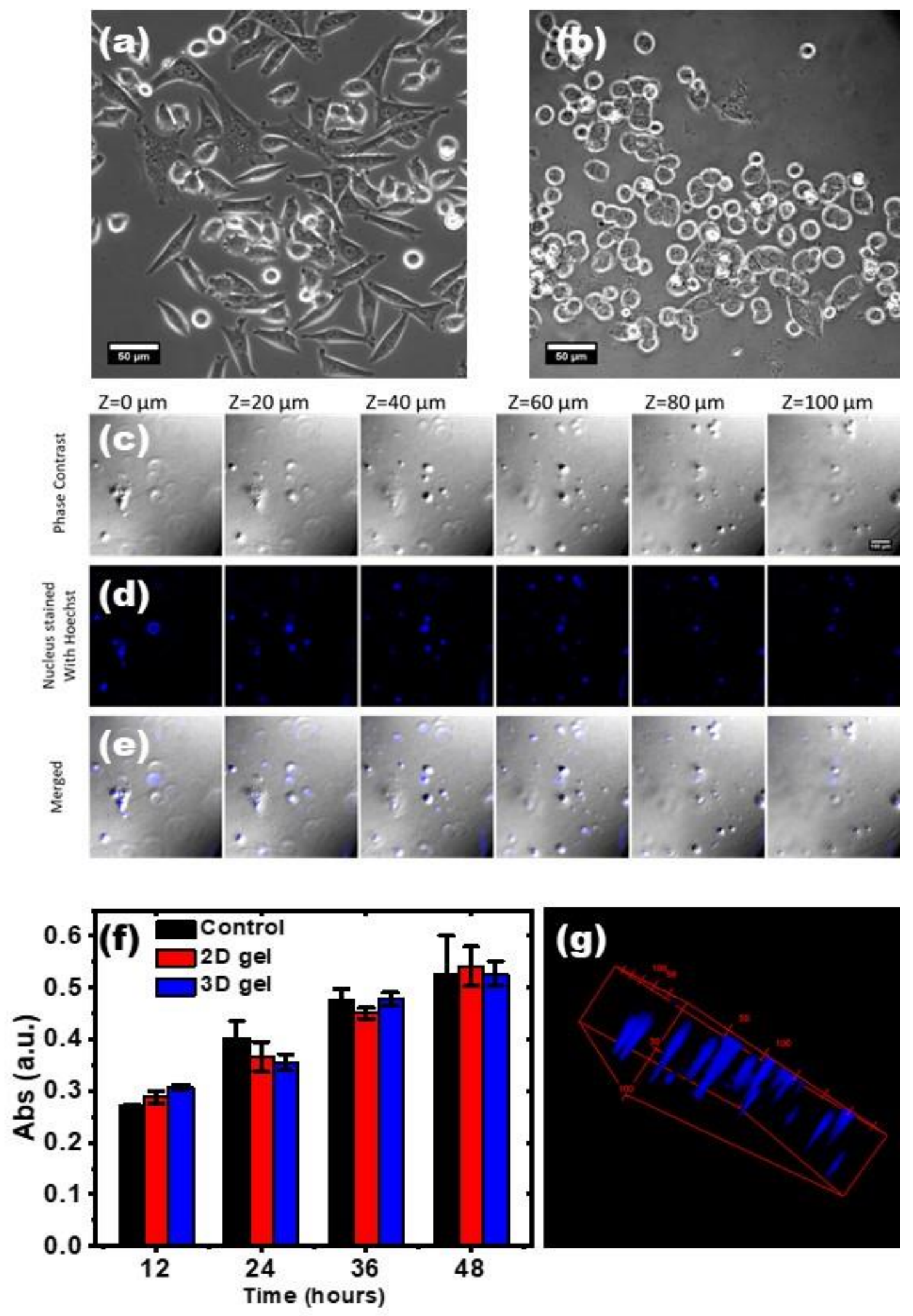

Figure 7.phase contrast images (20x magnification) of NIH 3 T3 cells cultured on the surface of (a) $1.5 \%(\mathrm{w} / \mathrm{v})$ gel and (b) glass, as control. Upon culturing cells on $1 \%(\mathrm{w} / \mathrm{v})$ hydrogel, it was 
observed that cells were present at different depths inside the gel, post 36 hours of seeding the cells on the surface, shown in (c) Phase contrast images; (d) Nuclei stained with Hoechst stain; (e) Merged (c) \& (d), Z indicates height from the glass surface.(f) MTT assay comparing viability of cells on glass surface (black), 1.5\% (w/v) gel for 2D culture (red) and 1\% (w/v) gel for 3D culture (blue). (g) 3D rendering of Hoechst stained cultured cell nuclei (blue). The elongated fluorescence in the Z-direction is due to the point spread function of the objective lens.

\section{Conclusion}

We demonstrated the formation of a histidine-containing peptide-based hydrogel at $\mathrm{pH} 7.5$. This study also convincingly demonstrates the tuning of mechanical stiffness and thermal stability of this peptide-based supramolecular hydrogel by incorporation of different dicarboxylic acids into the system, promoting hydrogen bonding and electrostatic interaction within the gel phase. We show for the first time that it is possible improvement of thermal and mechanical properties of a peptide hydrogel by introducing a dicarboxylic acid (succinic acid in 1:2 molar ratio) to promote acid base interaction in a two-component hydrogel system. Interestingly, the morphology of the native gel changes significantly in presence of succinic acid from bead-on-a-garland to a network of inter-connected helical nanofibers to form a two component hydrogel. The increased gel stiffness, the enhanced gel melting temperature and a nanofibrous network have been successfully utilized for the 3D/2D cell culture of fibroblast cells by using the two-component hydrogel as an extracellular matrix. This indicates that the tuning of mechanical strength, thermal stability and the morphology of the hydrogel promotes growth and nourishment of the cells in vitro pointing towards the future promise for peptide gel-based soft biomaterials in regenerative medicine. 


\section{AUTHOR INFORMATION}

\section{Corresponding Author}

*†Arindam Banerjee

\section{Notes}

The authors declare no competing financial interest.

\section{ACKNOWLEDGMENT}

D.B. and S.H. gratefully acknowledge UGC for their research fellowship. P.B. and K.B thank IACS for the financial support. We acknowledge Dr. P. Sen for being kind enough to donate us the MTT reagent. We also thank Mr. Rajib Moi and Mr. Krishna S. Das for carrying out the rheology experiments. IWH thanks EPSRC for the award of a Platform Grant (EP/L020599/1) and DH-M thanks ALBA (Cerdanyola del Vallès, Spain) for the award of synchrotron beamtime.

\section{REFERENCES}


(1) Dou, X. Q.; Feng, C. L. Amino Acids and Peptide-Based Supramolecular Hydrogels for Three-Dimensional Cell Culture. Adv. Mater.2017, 29, 1-21.

(2) Raeburn, J.; Adams, D. J.; Adams, D. J. Multicomponent Low Molecular Weight Gelators. Chem. Commun. 2015, 51, 5170-5180.

(3) Vemula, P. K.; John, G. Crops: A Green Approach toward Self-Assembled Soft Materials. Acc. Chem. Res.2008, 41,769-782.

(4) Datta, S.; Dey, N.; Bhattacharya, S. Electrochemical Probing ofHydrogelation Induced by the Self-assembly of a Donor-AcceptorComplex Comprising Pyranine and Viologen. Chem. Commun.2017, 53, 2371-2374.

(5) Panda, S. S.; Katz, H. E.; Tovar, J. D. Solid-State Electrical Applications of Protein and Peptide Based Nanomaterials. Chem. Soc. Rev.2018, 47, 3640-3658.

.(6) Kumar, M.; Ing, N. L.; Narang, V.; Wijerathne, N. K.; Hochbaum, A. I.; Ulijn, R. V. AminoAcid-Encoded Biocatalytic Self-Assembly Enables the Formation of Transient Conducting Nanostructures. Nat. Chem.2018, 10, 696-703.

(7) Lampel, A.; Ulijn, R. V.; Tuttle, T. Guiding Principles for Peptide Nanotechnology through Directed Discovery. Chem. Soc. Rev.2018, 47, 3737-3758.

(8) Tovar, J. D. Supramolecular Construction of Optoelectronic Biomaterials. Acc. Chem. Res.2013, 46, 1527-1537. 
(9) Feng, Z.; Zhang, T.; Wang, H.; Xu, B. Supramolecular Catalysis and Dynamic Assemblies. Chem. Soc. Rev.2017, 46, 6470-6479.

(10) Zozulia, O.; Dolan, M. A.; Korendovych, I. V. Catalytic Peptide Assemblies. Chem. Soc. Rev.2018, 47, 3621-3639.

(11) Gayen, K.; Basu, K.; Bairagi, D.; Castelletto, V.; Hamley, I. W.; Banerjee, A. Amino-AcidBased Metallo-Hydrogel That Acts Like an Esterase. ACS Appl. Bio Mater.2018. 1, 17171724.

(12) Paul, S.; Basu, K.; Das, S.; Banerjee, A. Peptide-Based Hydrogels as a Scaffold for In Situ Synthesis of Metal Nanoparticles: Catalytic Activity of the Nanohybrid System. ChemNanoMat. 2018, 4, 882-887.

(13) Feng, Y.; Wang, H.; Zhang, J.; Song, Y.; Meng, M.; Mi, J.; Yin, H.; Liu, L. Bioinspired Synthesis of $\mathrm{Au}$ Nanostructures Templated from Amyloid $\beta$ Peptide Assembly with Enhanced Catalytic Activity. Biomacromolecules2018, 19, 2432-2442.

(14) Nanda, J.; Biswas, A.; Adhikari, B.; Banerjee, A. Soft Matter A Gel-Based Trihybrid System Containing Nanofibers, Nanosheets, and Nanoparticles: Modulation of the Rheological Property and Catalysis.Angew. Chemie - Int. Ed.2013, 52, 5041-5045.

(15) Paul, S.; Gayen, K.; Nandi, N.; Banerjee, A. Carbon Nanodot-Induced Gelation of a Histidine-Based Amphiphile: Application as a Fluorescent Ink, and Modulation of Gel Stiffness. Chem. Commun. 2018, 54, 4341-4344. 
(16) Roy, S.; Basu, K.; Gayen, K.; Panigrahi, S.; Mondal, S.; Basak, D.; Banerjee, A. TiO 2 Nanoparticles Incorporated Peptide Appended PeryleneBisimide-Based Nanohybrid System: Enhancement of Photo- Switching Behavior. 2017. 121, 5428-5435.

(17) Okesola, B. O.; Smith, D. K. Applying Low-Molecular Weight Supramolecular Gelators in an Environmental Setting-Self-Assembled Gels as Smart Materials for Pollutant Removal. Chem. Soc. Rev.2016, 45, 4226-4251.

(18) Nandi, N.; Baral, A.; Basu, K.; Roy, S.; Banerjee, A. A Dipeptide-Based Superhydrogel : Removal of Toxic Dyes and Heavy Metal Ions from Waste Water. Pept. Sci.2017, 108, 19.

(19) Ray, S.; Das, A. K.; Banerjee, A. pH-Responsive,Bolaamphiphile-Based Smart MetalloHydrogels as Potential Dye-Adsorbing Agents, Water Purifier, and Vitamin B ${ }_{12}$ Carrier. Chem. Mater. 2007, 19, 1633-1639.

(20) Basak, S.; Nanda, J.; Banerjee, A. A New Aromatic Amino Acid Based Organogel for Oil Spill Recovery. J. Mater. Chem.2012, 22, 11658-11664.

(21) Basu, K.; Nandi, N.; Mondal, B.; Dehsorkhi, A.; Hamley, I. W.; Banerjee, A. Peptide-Based Ambidextrous Bifunctional Gelator: Applications in Oil Spill Recovery and Removal of Toxic Organic Dyes for Waste Water Management. Interface Focus2017, 7:20160128.

(22) Hellmund, K. S.; Koksch, B. Self-Assembling Peptides as Extracellular Matrix Mimics to Influence Stem Cell's Fate. Front. Chem.2019, 7, 1-8. 
(23) Li, Y.; Wang, F.; Cui, H. Peptide-Based Supramolecular Hydrogels for Delivery of Biologics. Bioeng. Transl. Med.2016, 1, 306-322.

(24) Sato, K.; Hendricks, M. P.; Palmer, L. C.; Stupp, S. I. Peptide Supramolecular Materials for Therapeutics. Chem. Soc. Rev.2018, 47, 7539-7551.

(25) Sahoo, J.K.;Braegelman, A.S.; Webber, M.J. J. Indian Inst. Sci.2018,98, 69-79.

(26) Qi, G. Bin; Gao, Y. J.; Wang, L.; Wang, H. Self-Assembled Peptide-Based Nanomaterials for Biomedical Imaging and Therapy. Adv. Mater.2018, 30, 1703444.

(27) Stern, D.; Cui, H. Crafting Polymeric and Peptidic Hydrogels for Improved Wound Healing. Adv. Healthc. Mater.2019, DOI: 10.1002/adhm.201900104.

(28) Carrejo, N. C.; Moore, A. N.; Lopez Silva, T. L.; Leach, D. G.; Li, I. C.; Walker, D. R.; Hartgerink, J. D. Multidomain Peptide Hydrogel Accelerates Healing of Full-Thickness Wounds in Diabetic Mice. ACS Biomater. Sci. Eng.2018, 4, 1386-1396.

(29) Wei, Q.; Duan, J.; Ma, G.; Zhang, W.; Wang, Q.; Hu, Z. Enzymatic Crosslinking to Fabricate Antioxidant Peptide-Based Supramolecular Hydrogel for Improving Cutaneous Wound Healing. J. Mater. Chem. B2019, 7, 2220-2225.

(30) Koch, F.; Wolff, A.; Mathes, S.; Pieles, U.; Saxer, S. S.; Kreikemeyer, B.; Peters, K. Amino Acid Composition of Nanofibrillar Self-Assembling Peptide Hydrogels Affects Responses of Periodontal Tissue Cells in Vitro. Int. J. Nanomedicine2018, 13, 6717-6733. 
(31) Kisiday, J.; Jin, M.; Kurz, B.; Hung, H.; Semino, C.; Zhang, S.; Grodzinsky, A. J. SelfAssembling Peptide Hydrogel Fosters Chondrocyte Extracellular Matrix Production and Cell Division: Implications for Cartilage Tissue Repair. Proc. Natl. Acad. Sci.2002, 99, 9996-10001.

(32) Wang, H.; Yang, Z. Short-Peptide-Based Molecular Hydrogels: Novel Gelation Strategies and Applications for Tissue Engineering and Drug Delivery. Nanoscale2012, 4, 5259-5267.

(33) Tibbitt, M. W.; Anseth, K. S. Hydrogels as Extracellular Matrix Mimics for 3D Cell Culture. Biotechnol. Bioeng.2009, 103, 655-663.

(34) Nandi, N.; Gayen, K.; Ghosh, S.; Bhunia, D.; Kirkham, S.; Sen, S. K.; Ghosh, S.; Hamley, I. W.; Banerjee, A. Amphiphilic Peptide-Based Supramolecular, Noncytotoxic, StimuliResponsive Hydrogels with Antibacterial Activity. Biomacromolecules2017, 18, 36213629.

(35) Baral, A.; Roy, S.; Ghosh, S.; Hermida-Merino, D.; Hamley, I. W.; Banerjee, A. A PeptideBased Mechano-Sensitive, Proteolytically Stable Hydrogel with Remarkable Antibacterial Properties. Langmuir2016, 32, 1836-1845.

(36) Salick, D. A.; Pochan, D. J.; Schneider, J. P. Design of an Injectable $\beta$-Hairpin Peptide Hydrogel That Kills Methicillin-Resistant Staphylococcus Aureus. Adv. Mater.2009, 21, $4120-4123$. 
(37) Veiga, A. S.; Sinthuvanich, C.; Gaspar, D.; Franquelim, H. G.; Castanho, M. A. R. B.; Schneider, J. P. Arginine-Rich Self-Assembling Peptides as Potent Antibacterial Gels. Biomaterials2012, 33, 8907-8916.

(38) Hu, B.; Owh, C.; Chee, P. L.; Leow, W. R.; Liu, X.; Wu, Y. L.; Guo, P.; Loh, X. J.; Chen, X. Supramolecular Hydrogels for Antimicrobial Therapy. Chem. Soc. Rev.2018, 47, 69176929.

(39) Dimatteo, R.; Darling, N. J.; Segura, T. In Situ Forming Injectable Hydrogels for Drug Delivery and Wound Repair. Adv. Drug Deliv. Rev.2018, 127, 167-184.

40) Sun, J. E. P.; Stewart, B.; Litan, A.; Lee, S. J.; Schneider, J. P.; Langhans, S. A.; Pochan, D. J. Sustained Release of Active Chemotherapeutics from Injectable-Solid $\beta$-Hairpin Peptide Hydrogel. Biomater. Sci.2016, 4, 839-848.

(41) Raymond, D. M.; Abraham, B. L.; Fujita, T.; Watrous, M. J.; Toriki, E. S.; Takano, T.; Nilsson, B. L. Low Molecular Weight Supramolecular Hydrogels for Sustained and LocalizedIn Vivo Drug Delivery. ACS Appl. Bio Mater.2019, DOI: 10.1021/acsabm.9b00125.

(42) Falcone, N.; Kraatz, H. B. Supramolecular Assembly of Peptide and MetallopeptideGelators and Their Stimuli-Responsive Properties in Biomedical Applications. Chem. - A Eur. J.2018, 24, 14316-14328. 
(43) Urakami, H.; Guan, Z. Living Ring-Opening Polymerization of a Carbohydrate-Derived Lactone for the Synthesis of Protein-Resistant Biomaterials. Biomacromolecules2008, 9, $592-597$.

(44) Arioz, I.; Erol, O.; Bakan, G.; Dikecoglu, F. B.; Topal, A. E.; Urel, M.; Dana, A.; Tekinay, A. B.; Guler, M. O. Biocompatible Electroactive Tetra(Aniline)-Conjugated Peptide Nanofibers for Neural Differentiation. ACS Appl. Mater. Interfaces2018, 10, 308-317.

(45) Koutsopoulos, S. Self-Assembling Peptide Nanofiber Hydrogels in Tissue Engineering and Regenerative Medicine: Progress, Design Guidelines, and Applications. J. Biomed. Mater. Res. - Part A2016, 104, 1002-1016.

(46) Matson, J. B.; Stupp, S. I. Self-Assembling Peptide Scaffolds for Regenerative Medicine. Chem. Commun.2012, 48, 26-33.

(47) Yergoz, F.; Hastar, N.; Cimenci, C. E.; Ozkan, A. D.; Guler, M. O.; Tekinay, A. B.; Tekinay, T.; Guler, M. O. Heparin Mimetic Peptide Nanofiber Gel Promotes Regeneration of Full Thickness Burn Injury. Biomaterials2017, 134, 117-127.

(48) Jayawarna, V.; Ali, M.; Jowitt, T. A.; Miller, A. F.; Saiani, A.; Gough, J. E.; Ulijn, R. V. Nanostructured Hydrogels for Three-Dimensional Cell Culture through Self-Assembly of Fluorenylmethoxycarbonyl-Dipeptides. Adv. Mater.2006, 18, 611-614.

(49) Zanna, N.; Focaroli, S.; Merlettini, A.; Gentilucci, L.; Teti, G.; Falconi, M.; Tomasini, C. Thixotropic Peptide-Based Physical Hydrogels Applied to Three-Dimensional Cell Culture. ACS Omega2017, 2, 2374-2381. 
(50) Worthington, P.; Drake, K. M.; Li, Z.; Napper, A. D.; Pochan, D. J.; Langhans, S. A. BetaHairpin Hydrogels as Scaffolds for High-Throughput Drug Discovery in ThreeDimensional Cell Culture. Anal. Biochem.2017,535. 25-34.

(51) Draper, E. R.; Adams, D. J. PhotoresponsiveGelators. Chem. Commun.2016, 52, 81968206.

(52) Colquhoun, C.; Draper, E. R.; Eden, E. G. B.; Cattoz, B. N.; Morris, K. L.; Chen, L.; McDonald, T. O.; Terry, A. E.; Griffiths, P. C.; Serpell, L. C.; et al. The Effect of SelfSorting and Co-Assembly on the Mechanical Properties of Low Molecular Weight Hydrogels. Nanoscale2014, 6, 13719-13725.

(53) Micklitsch, C. M.; Knerr, P. J.; Branco, M. C.; Nagarkar, R.; Pochan, D. J.; Schneider, J. P. Zinc-Triggered Hydrogelation of a Self-Assembling $\beta$-Hairpin Peptide. Angew. Chemie Int. Ed.2011, 50, 1577-1579.

(54) Chakraborty, P.; Guterman, T.; Adadi, N.; Yadid, M.; Brosh, T.; Adler-Abramovich, L.; Dvir, T.; Gazit, E. A Self-Healing, All-Organic, Conducting, Composite Peptide Hydrogel as Pressure Sensor and Electrogenic Cell Soft Substrate. ACS Nano2019, 13, 163-175.

(55) Levental, I.; Georges, P. C.; Janmey, P. A. Soft Biological Materials and Their Impact on Cell Function. Soft Matter2007, 3, 299-306.

(56) Engler, A. J.; Sen, S.; Sweeney, H. L.; Discher, D. E. Matrix Elasticity Directs Stem Cell Lineage Specification. Cell2006, 126, 677-689. 
(57) Boothroyd, S.; Saiani, A.; Miller, A. F. Controlling Network Topology and Mechanical Properties of Co-Assembling Peptide Hydrogels. Biopolymers2014, 101, 669-680.

(58) Scelsi, A.; Bochicchio, B.; Smith, A.; Workman, V. L.; Castillo Diaz, L. A.; Saiani, A.; Pepe, A. Tuning of Hydrogel Stiffness Using a Two-Component Peptide System for Mammalian Cell Culture. J. Biomed. Mater. Res. - Part A2019, 107, 535-544.

(59) Mosmann, T. Rapid Colorimetric Assay for Cellular Growth and Survival: Application to Proliferation and Cytotoxicity Assays. J. Immunol. Methods1983, 65, 55-63.

(60) Srivastava, A.; Ghorai, S.; Bhattacharjya, A.; Bhattacharya, S. A Tetrameric Sugar-Based Azobenzene That Gels Water at Various PH Values and in the Presence of Salts. J. Org. Chem.2005, 70, 6574-6582.

(61) Cai, X.; Wu, Y.; Wang, L.; Yan, N.; Liu, J.; Fang, X.; Fang, Y. Mechano-Responsive Calix[4]Arene-Based Molecular Gels: Agitation Induced Gelation and Hardening. Soft Matter2013, 9, 5807-5814.

(62) Ye, F.; Chen, S.; Tang, G. D.; Wang, X. Sonication Induced Morphological Transformation between 3D Gel Network and Globular Structure in a Two-Component Gelation System. Colloids Surfaces APhysicochem. Eng. Asp.2014, 452, 165-172.

(63) Zhou, Y.; Xu, M.; Yi, T.; Xiao, S.; Zhou, Z.; Li, F.; Huang, C. Morphology-Tunable and Photoresponsive Properties in a Self-Assembled Two-Component Gel System. Langmuir2007, 23, 202-208. 
(64) Nanda, J.; Biswas, A.; Banerjee, A. Single Amino Acid Based Thixotropic Hydrogel Formation and PH-Dependent Morphological Change of Gel Nanofibers. Soft Matter2013, 9, 4198-4208.

(65) Haldar, D.; Drew, M. G. B.; Banerjee, A. $\alpha$-Aminoisobutyric Acid Modified Protected Analogues of $\beta$-Amyloid Residue 17-20: A Change from Sheet to Helix. Tetrahedron2006, 62, 6370-6378.

(66) Liu, Y.; Wang, T.; Liu, M. Supramolecular Polymer Hydrogels from Bolaamphiphilic L Histidine and Benzene Dicarboxylic Acids: Thixotropy and Significant Enhancement of Eu III Fluorescence. Chem. - A Eur. J.2012, 18, 14650-14659.

(67) Baral, A.; Roy, S.; Dehsorkhi, A.; Hamley, I. W.; Mohapatra, S.; Ghosh, S.; Banerjee, A. Assembly of an Injectable Noncytotoxic Peptide-Based Hydrogelator for Sustained Release of Drugs. Langmuir2014, 30, 929-936.

(68) Pacios, L. F.; Gálvez, O.; Gómez, P. C. Variation of Geometries and Electron Properties along Proton Transfer in Strong Hydrogen-Bond Complexes. J. Chem. Phys.2005, 122, .214307 .

(69) Trachsel, M. A.; Ottiger, P.; Frey, H. M.; Pfaffen, C.; Bihlmeier, A.; Klopper, W.; Leutwyler, S. Modeling the Histidine-Phenylalanine Interaction: The $\mathrm{NH}^{\cdots} \pi$ Hydrogen Bond of Imidazole. Benzene. J. Phys. Chem. B2015, 119, 7778-7790.

(70) Guo, W. H.; Frey, M. T.; Burnham, N. A.; Wang, Y. L. Substrate Rigidity Regulates the Formation and Maintenance of Tissues. Biophys. J.2006, 90, 2213-2220. 
(71) Li, J.; Han, D.; Zhao, Y. P. Kinetic Behaviour of the Cells Touching Substrate: The Interfacial Stiffness Guides Cell Spreading. Sci. Rep.2014, 4, 1-11.

(72) Vertelov, G.; Gutierrez, E.; Lee, S. A.; Ronan, E.; Groisman, A.; Tkachenko, E. Rigidity of Silicone Substrates Controls Cell Spreading and Stem Cell Differentiation. Sci. Rep.2016, $6,1-6$.

(73) Solon, J.; Levental, I.; Sengupta, K.; Georges, P. C.; Janmey, P. A. Fibroblast Adaptation and Stiffness Matching to Soft Elastic Substrates. Biophys. J.2007, 93, 4453-4461.

(74) Tee, S. Y.; Fu, J.; Chen, C. S.; Janmey, P. A. Cell Shape and Substrate Rigidity Both Regulate Cell Stiffness. Biophys. J.2011, 100, 25-27.

(75) Scherzer, M. T.; Waigel, S.; Donninger, H.; Arumugam, V.; Zacharias, W.; Clark, G.; Siskind, L. J.; Soucy, P.; Beverly, L. Fibroblast-Derived Extracellular Matrices: An Alternative Cell Culture System That Increases Metastatic Cellular Properties. PLoS One2015, 10, 1-17.

(76) Jansen, K. A.; Bacabac, R. G.; Piechocka, I. K.; Koenderink, G. H. Cells Actively Stiffen Fibrin Networks by Generating Contractile Stress. Biophys. J.2013, 105, 2240-2251. 


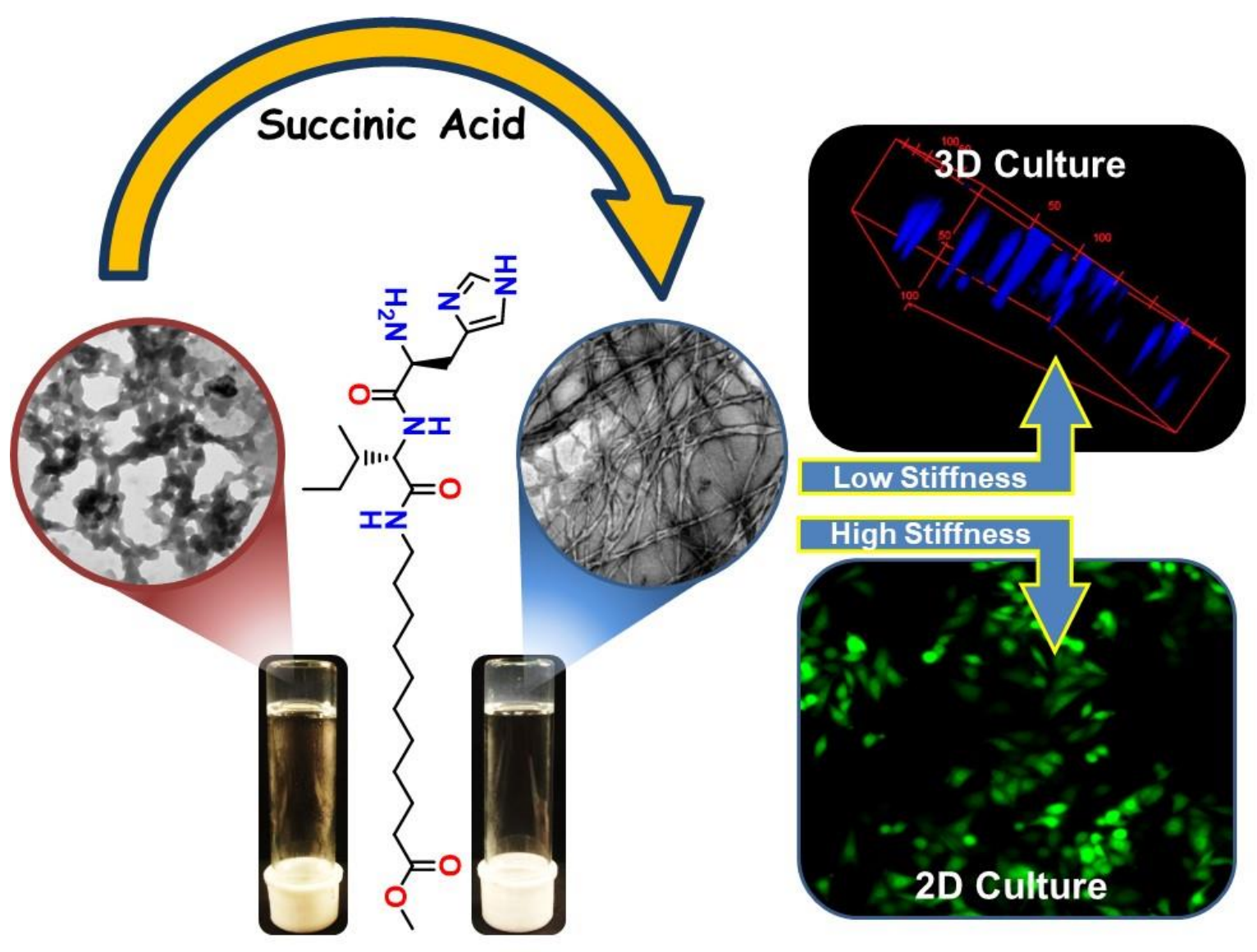

